\title{
The Role of Macroeconomic Policies on Savings Mobilization in Nigeria
}

\author{
Momoh Abdulazeez O. Jimah Abdulminiru \\ Department of Humanities and Social Sciences, Auchi Polytechnic, Auchi
}

\begin{abstract}
This research work analyzed the roles of macroeconomic policies on savings mobilization in Nigeria (1985-2018) empirically. The secondary data were adopted and sourced from CBN. Ordinary Least Square and Cointegration were used to determine the role of the selected macroeconomic policies on savings mobilization in Nigeria. The aftereffect of the overall statistic showed that there is a positive and significant impact between the macroeconomic variables and domestic savings mobilization in Nigeria. But in particular, financial deepening appeared to have a greater impact on savings mobilization in Nigeria. Exchange rate and inflation uncovered a reverse relationship with domestic saving mobilization in Nigeria. The Augmented Dickey-Fuller (ADF) unit root tests and cointegration demonstrated that the variables are stationary and there exists a long-run relationship among the variables. The study hence recommended among others that efforts should be geared towards continuous and all-around fiscal and monetary policies that will sustain this development in the financial sector. Additionally, the government ought to guarantee that adequate macroeconomic policies will be set up to attract foreign investors, encourage export, and make Nigeria an export platform where export goods could be delivered, this will assist with strengthening Nigeria's exchange rate incite domestic savings. Finally, appropriate measures ought to be placed into encouraging banks to open branches in rural areas to mop up deposits. The rural banking policies should be returned to adjusted and implemented in Nigeria.
\end{abstract}

DOI: $10.7176 / \mathrm{JESD} / 12-4-02$

Publication date: February $28^{\text {th }} 2021$

\section{BACKGROUND TO THE STUDY}

Macroeconomic policies include taxes, government spending and borrowing, exchange rate determinants, and monetary and credit rules. The primary goal of effective macroeconomic policies is to reduce uncertainty and risk in economic decision-making. A stable macroeconomic environment enhances prospects for growth and improved living standards.

The mobilization of savings embraces policies designed to increase the savings propensity and policies concerned with the rechanneling of savings to facilitate the desired location of investment. Also, capital formation through savings mobilization is an important factor in economic growth. Countries that can accumulate a high level of capital tend to achieve faster rates of economic growth and development (Uremadu, 2003). Savings provide developing countries like Nigeria with the much-needed capital for investment which improves economic growth. Increase in savings leads to an increase in capital formation and production activities that will, in turn, lead to employment creation and reduce external borrowings of government.

However, savings represent that part of income that is not spent on consumption but when applied to capital investment, output increases (Olusoji, 2013). Savings mobilization has been regarded as a key growth performance indicator. However, the correlation between savings and the rate of growth of income is not strong, nor can countries been ranked in their growth performance by their saving performance (Wiseman et al, 2007). Changes in macroeconomic variables impact on the structure and the level of savings of the financial sector. The linkage between macroeconomic variables and savings and economics performance becomes significant in a developing economy like Nigeria with underdeveloped market structure. Specifically, high rate of inflation, low disposable income and low spread of bank branches tend to put pressure on the level of savings while monetary shocks will tend to put pressure on the price level of bank balance sheet.

Nevertheless, capital accumulation has been emphasized as the major factor governing the rate of development. This accumulation of real physical capital stock has been viewed as permitting a more roundabout method of production and greater productivity, thereby providing an additional future stream of income to society. Whether it is financed from internal to external sources, the accumulation of capital in any developing economy requires the mobilization of economic surplus (Meir, 2001). That is for an economy that wants to increase its real capital formation the objective must be to provide a climate receptive to the importation of resources from outside and the encouragement of domestic savings.

In developing countries (such as Nigeria), experiences have shown that foreign capital alone cannot create any permanent basis for a higher standard of living in future and that greater planned economic development (Agu, 2005). More so, the current trends in the flow of assistance to developing countries are declining and are not keeping pace with actual needs. At a time when all countries need an ever-increasing volume of resources to promote their economic development, it has become difficult to secure foreign funds; and resource to such funds 
entails serious disadvantages because it creates serious economic dependency upon the creditor countries and increases the burden of debt.

The economic realities in Nigeria have therefore considerably reinforced these arguments in favour of the greater emphasis on domestic resource mobilization. The Nigerian data reveals a small volume of savings and a low voluntary saving rate as low as $8 \%$. In the past two decades, the country also witnessed an atmosphere of crisis and disappointment. The nation's situation was in many ways dramatic; which resulted in enormous and fast-growing deficits. This is in addition to the country's heavy debt burden. The aid has also stagnated and the conditions of international credits are becoming tougher and the possibilities to increase Nigeria's exports are diminishing as the recession deepens. It is therefore increasingly evident on the greater need and effort to mobilize domestic saving in Nigeria if a desired economic development is to be achieved. This depends on domestic sources of capital, therefore requires a wide range of independent well-organized and adapted financial institution, which has to mobilize internal resources for capital formation and allow the capital to be invested conveniently and freely into desired development ventures. At the point when allocated to capital investment, savings reserve funds increment yield. Establishments in the financial sector, similar to the business banks, mobilize savings in different manners including investment on which they pay certain intrigue. To viably activate mobilize savings in an economy, the deposit rate must be relatively high and inflation rate stabilized to ensure a high positive real interest rate, which inspires investors to save from their disposable income. Individuals have likewise to discover the organizations adequately safer than other alternatives. Economic and political stability also plays a preponderant role, as well as monetary regulation. Also, the age structure of the population, estimated by the ratio of the populace defined as a dependent (under 15 years and over 64 years) to the total population (for example dependency ratio) constitutes another significant determination of domestic savings as found in the works of (Khan, 1988, Akhter, 1986; Burney and Khan, 1992 and Chete, 1999) following the above reasoning, the larger the population of the working-age population in a country, the more the aggregate lifetime income and thus, the higher the total aggregate savings. Based on the research objectives, the study endeavours to give answers to the following questions: What the core determinants of savings mobilization in Nigeria? How efficient is the financial intermediation process (savings mobilization) in Nigeria? and What are the effects of branch banking in savings mobilization in Nigeria?

The main objective is to examine the role of macroeconomic policies on saving mobilization in Nigeria. However, the following specific objectives would also be achieved: To determine the effectiveness of domestic savings mobilization on the Nigerian economy and to identify the effects of branch banking in savings mobilization in Nigeria.

The study is beneficial to stakeholders in the financial sector, monetary authority, government, academic and students. The study would provide empirical evidence upon which to assess the role of macroeconomic policy on savings mobilization in Nigeria. The study would also provide policy recommendations to policymakers on ways to patch up the economy through macroeconomic policy.it also addresses the fact that the low level of savings in the Nigerian economy limits the investment rates on which economic growth depends. Thus a holistic approach to mobilizing savings within interest rate is a major policy strategy that makes study relevant. This study also provides policies as it relates to macroeconomic policies and saving mobilization in the Nigeria economy. The study would also be significant in its outing ways because the research would highlight some vital functions of macroeconomic policies in saving formation. The research work will touch on how macroeconomic policies have aided the mobilization of savings for tending the sectors of the economy. Also, it has been observed that despite the effort being made, the macroeconomic policy is yet to effectively realize this great role. The critics of its operation have buttressed by pointing out several problems which besiege macroeconomic policies in terms of savings mobilization. The focus of the study is highly justified especially when examining empirically the role of macroeconomic policies on savings mobilization in Nigeria. A lot of savings are not being mobilized, and a lot remains idle or dissipated owing to lack of institutions to mobilize them (Khatkhate and Riechel, 2010). Nigeria still has a long way to go in habituating the people to effective modern banking system. Academic and students will benefit from the study as it provides an objective view of the role of macroeconomic policy in Nigeria and also serve as a basis for further research.

The hypotheses to be tested in this research work are shown below:

i. Ho: Macroeconomic variables have no significant impact on savings mobilization in Nigeria.

Hi: Macroeconomic variables have significant impact on savings mobilization in Nigeria.

ii. Ho: There is no significant relationship between bank branches and savings mobilization in Nigeria. Hi: There is significant relationship between bank branches and savings mobilization in Nigeria.

\section{METHODOLOGY}

Theoretical Framework

According to the standard Keynesian macroeconomic theory: $\mathrm{S}=\mathrm{f}(\mathrm{Y}, \mathrm{I} \mathrm{W})$ 
Where $\mathrm{S}=$ rate of savings, $\mathrm{Y}=$ income, $\mathrm{I}=$ rate of interest and $\mathrm{W}=$ wealth. Financial technology is not among the explicit arguments of the above equation. Due to the synchronization of the receipt and disbursement of income is an important objective of saving entities, the kind of financial instruments made available by financial intermediaries will affect the magnitude of savings.

Savings, therefore cannot be regarded as a given datum available portfolio choice. The volume of savings is influenced by financial technology and therefore equation (1) may be re-specified as:

$$
\begin{aligned}
& \mathrm{S}=\mathrm{f}(\mathrm{y}, \mathrm{I}, \mathrm{w}, \mathrm{t}) \\
& \text { Where } \mathrm{t}=\sum_{\mathrm{J}} \sum_{\mathrm{x} \mathrm{n}} \mathrm{A}_{\text {jn }} \text { and }
\end{aligned}
$$

$\mathrm{A}_{\mathrm{jn}}=$ the monetary value of the nth asset of the jth institution of the financial market. The technology $(\mathrm{t})$ however, depends on several factors such as the extent to which the business units depend on external sources for their finance, and how much on internal financing. The technique used in this research work is the quantitative method. The researcher chooses to integrate the different component of the role of macroeconomic policies on savings mobilization in Nigeria in an empirical way, thereby ensuring effective quantitative address of the research problem. It constitutes the blueprint for the collection, measurement and analysis of data.

\section{Method of Data Analysis}

The study will cover the period of 1985-2020. Regression analysis based on the classical linear regression model, otherwise known as Ordinary Least Square (OLS) technique is chosen by the researcher. The researcher's choice of this technique is based not only by its computational simplicity but also as a result of its optional properties, such as linearity, unbiasedness, minimum variance, zero mean value of the random terms (Gujaratis, 2004). Also, the state art of econometric tools analysis are employed:

- Unit root test

- Cointegration test

- Granger Causality test

To test for unit root and the other of integration of the variables in our data set, we employed the Augmented Dickey-Fuller (ADF) test. The ADF test for unit root indicates whether an individual series is stationary or not. Existence of unit roots in a series denotes non-stationarity.

ADF tests are used for the stationary of the series to be sure that we are not analyzing inconsistent and spurious relationships. The basic idea behind cointegration is that if in the long-run, two or more series move closely together, even though the series themselves are trended, the difference between them is constant. A lack of cointegration suggests that such variables have no long-run relationship. Also, the Granger causality test will be applied in this study as a means of ascertaining causality among the two variables-savings mobilization on one hand and macroeconomic variables on the other hand. Basically, Granger measures precedence and information content.

\section{Model Specification}

Since the main focus is to have a better understanding of the impact of macroeconomic policies on domestic savings in Nigeria. The thrust of this research is to thoroughly investigate the impact of macroeconomic policies on savings mobilization in Nigeria. Therefore, the model for this research is specified thus;

$\mathrm{DS}=(\mathrm{Infr}, \mathrm{Dr}, \mathrm{Er}, \mathrm{Nb}, \mathrm{Pky}, \mathrm{Fdv})$

$$
\mathrm{DS}=a_{0}+a_{1} I n f r+a_{2} D r+a_{3} E r+a_{4} N b+a_{5} P k y+a_{6} F d v+U
$$

Where;

$\begin{array}{lll}\mathrm{DS} & = & \text { Domestic Saving } \\ \mathrm{Infr} & = & \text { Inflation Rate } \\ \mathrm{Dr} & = & \text { Deposit Rate } \\ \mathrm{Er} & = & \text { Naira/Dollar Exchange Rate } \\ \mathrm{Nb} & = & \text { Number of Bank Branches } \\ \mathrm{Pky} & = & \text { Per Capital Income } \\ \mathrm{Fdv} & = & \text { Financial Deepening Variable } \\ \mathrm{U} & = & \text { Error Term or Stochastic Variable } \\ \alpha_{0} & = & a_{1}, a_{2}, a_{3_{2}} a_{4} a_{5}, a_{6} \text { are parameter to be estimated } \\ \mathrm{The} & \text { expected } \quad \text { signs } \quad \text { of coefficient or }\end{array}$

apririori expectation are

$a_{1}<0 ; a_{2}>0 ; a_{3}>0 ; a_{4}>0 ; a_{5}>0 ; a_{6}>0$. Deposit rate, exchange rate, per capita income, financing deepening and number of banks are expected to have a direct relationship with domestic savings, while inflation rate is expected to have an inverse relationship with domestic savings. i.e. $a_{2}, a_{3}, a_{4}, a_{5}, a_{6}>0 ; a_{1}<0$. 


\section{PRESENTATION AND INTERPRETATION OF RESULT}

The table above shows the result of the descriptive statistics of the variables used in the analysis. The result shows that from 1985-2018 the average domestic savings, inflation rate, deposit rate, exchange rate, per capita income, financial deepening and number of banks were 3319.591, 19.5821, 7.318, 99.012, 1262.616, 14.614, 45.706 respectively. These indicate that the variables exhibit significant variation in terms of magnitude, suggesting that estimation at levels may introduce some bias in the result. It is observed that all the variables are positively skewed, meaning they have rising overtime. The descriptive analysis also revealed that domestic savings and inflation rate were normally distributed, while deposit rate, exchange rate, per capita income, financial deepening and number of banks were not as observed from the Jarque- Bera probability.

Table 1: Descriptive Statistics

\begin{tabular}{|l|l|l|l|l|l|l|l|}
\hline & DS & INFR & DR & ER & PKY & FD & NB \\
\hline Mean & 3319.591 & 19.5821 & 7.318 & 99.012 & 1262.616 & 14.614 & 45.706 \\
\hline Skewness & 1.225 & 1.653 & 0.787 & 0.684 & 0.682 & 0.439 & 0.605 \\
\hline Jarque-Bera & 8.511 & 18.115 & 4.709 & 2.664 & 4.095 & 3.604 & 3.312 \\
\hline Probability & 0.014 & 0.0000 & 0.095 & 0.264 & 0.129 & 0.165 & 0.191 \\
\hline observations & 34 & 34 & 34 & 34 & 34 & 34 & 34 \\
\hline
\end{tabular}

\section{Unit Root Test Results}

The Augmented Dickey-Fuller (ADF) test was employed to test for the presence of unit root. The result shows that only domestic savings at stationary at levels, while the variables of inflation rate, deposit rate, exchange rate, per capita income, financial deepening and number of banks were found to be stationary at first difference.

Table 2: Unit Root Results

\begin{tabular}{|c|c|c|c|c|c|}
\hline \multirow[t]{2}{*}{ Variables } & \multicolumn{2}{|l|}{ Value@ levels } & \multicolumn{2}{|c|}{ Values@1 $1^{\text {st }}$ Diff } & \multirow[b]{2}{*}{ Remark } \\
\hline & $\begin{array}{ll}\text { ADF } & \text { Test } \\
\text { Statistics } & \\
\end{array}$ & $\begin{array}{l}\text { Critical Value } \\
\text { @,5\% }\end{array}$ & $\begin{array}{l}\text { ADF Test } \\
\text { Statistics }\end{array}$ & $\begin{array}{l}\text { Critical Value } \\
\text { @ } 5 \%\end{array}$ & \\
\hline $\mathrm{DS}$ & 3.096 & -2.986 & 0.961 & -2.992 & $/(0)$ \\
\hline INFR & -2.113 & -2.981 & -3.256 & -2.992 & $/(1)$ \\
\hline DR & -0.960 & -2.954 & -5.812 & -2.957 & $/(1)$ \\
\hline ER & 1.385 & -2.954 & -4.039 & -2.957 & $/(1)$ \\
\hline PKY & -0.955 & -2.957 & -3.953 & -2.957 & $/(1)$ \\
\hline FD & -0.992 & -2.954 & -5.293 & -2.957 & $/(1)$ \\
\hline NB & -1.668 & -2.954 & -5.225 & -2.957 & $/(1)$ \\
\hline
\end{tabular}

\section{Co-integration Test Results}

Since the variables are integrated of a different order, the method of co-integration test is employed is the Johanson co-integration investigating method which is a system equation. According to the rule, all that is required to ensure co-integrating is at least on the con-integrating equation. The result is as presented below.

Table 3: Johansson co-integration Test Result

\begin{tabular}{|l|c|l|l|l|}
\hline \multicolumn{4}{|c|}{ Trace Statistics } & \multicolumn{2}{l|}{ Max-Eigen Statistics } \\
\hline $\begin{array}{l}\text { Hypothesized No. of } \\
\mathrm{CE}(\mathrm{s})\end{array}$ & $\begin{array}{l}\text { Trace } \\
\text { Statistic }\end{array}$ & $\begin{array}{l}\text { Critical Value } \\
5 \%\end{array}$ & $\begin{array}{l}\text { Max-Eigen } \\
\text { Statistic }\end{array}$ & $\begin{array}{l}\text { Critical Value @ } \\
5 \%\end{array}$ \\
\hline $\mathrm{r}=0^{*}$ & 178.5071 & 125.6154 & 62.63981 & 46.23142 \\
\hline $\mathrm{r}=1^{*}$ & 115.8673 & 95.75366 & 42.75402 & 40.07757 \\
\hline $\mathrm{r}=2^{*}$ & 73.11326 & 69.81889 & 26.19669 & 33.87687 \\
\hline $\mathrm{r}=3$ & 46.91658 & 47.85613 & 18.75219 & 27.58434 \\
\hline $\mathrm{r}=4$ & 28.16438 & 29.79707 & 17.12396 & 21.13162 \\
\hline $\mathrm{r}=5$ & 11.04042 & 15.49471 & 10.06707 & 14.26460 \\
\hline $\mathrm{r}=6$ & 0.973351 & 3.841466 & 0.973351 & 3.841466 \\
\hline
\end{tabular}

From the trace statistic, it can be seen that there are at least three co-integrating equations, whereas in the Max-Eigen statistic there is at least two co-integrating equation. This confirms therefore that there is cointegrating between the dependent and the independent variables of each of the model.

\section{Vector Error Correction Model (VECM) Test}

Since the order of integration is not the same, it means that we are not permitted to adopt a linear equation modelling such as ECM because literature says for ECM to be adopted series must be integrated of the same order. Now that they are integrated into different order it means that the only way forward is to adopt a system equation method. The study, therefore, decides to adopt VECM since it is theoretically justified, unlike VAR that is theoretical. The result is as presented below. 
Table 4. Vector Error Correction Model (VECM) Result

\begin{tabular}{|c|c|c|c|c|c|c|c|}
\hline $\begin{array}{l}\text { Explanatory } \\
\text { Variables }\end{array}$ & $\mathrm{D}(\mathrm{DS})$ & D(INFR) & $\mathrm{D}(\mathrm{DR})$ & $\mathrm{D}(\mathrm{ER})$ & $\mathrm{D}(\mathrm{PCI})$ & $\mathrm{D}(\mathrm{FDV})$ & $\mathrm{D}(\mathrm{NB})$ \\
\hline ECM & $\begin{array}{l}0.765 \\
(2.948)\end{array}$ & $\begin{array}{l}0.001 \\
(0.224)\end{array}$ & $\begin{array}{l}0.001 \\
(1.000)\end{array}$ & $\begin{array}{l}0.015 \\
(2.883)\end{array}$ & $\begin{array}{l}-0.124 \\
(-1.443)\end{array}$ & $\begin{array}{l}0.000 \\
(0.273)\end{array}$ & $\begin{array}{l}-0.005 \\
(-0.816)\end{array}$ \\
\hline $\mathrm{D}(\mathrm{DS}(-1))$ & $\begin{array}{l}-1.387 \\
(-2.775)\end{array}$ & $\begin{array}{l}-0.005 \\
(-0.466)\end{array}$ & $\begin{array}{l}-0.001 \\
(-0.893)\end{array}$ & $\begin{array}{l}-0.022 \\
(-2.119)\end{array}$ & $\begin{array}{l}0.129 \\
(0.776)\end{array}$ & $\begin{array}{l}-0.001 \\
(-0.690)\end{array}$ & $\begin{array}{l}0.009 \\
(0.808)\end{array}$ \\
\hline $\mathrm{D}(\mathrm{DS}(-2))$ & $\begin{array}{l}-0.436 \\
(-1.216)\end{array}$ & $\begin{array}{l}-0.022 \\
(-0.244)\end{array}$ & $\begin{array}{l}-0.001 \\
(-0.704)\end{array}$ & $\begin{array}{l}-1.000 \\
(-1.312)\end{array}$ & $\begin{array}{l}0.055 \\
(0.460)\end{array}$ & $\begin{array}{l}-0.000 \\
(-0.434)\end{array}$ & $\begin{array}{l}0.005 \\
(0.668)\end{array}$ \\
\hline $\mathrm{D}(\mathrm{INFR}(-1))$ & $\begin{array}{l}-14.219 \\
{[-1.383]}\end{array}$ & $\begin{array}{l}-0.102 \\
{[-0.438]}\end{array}$ & $\begin{array}{l}0.056 \\
{[2.230]}\end{array}$ & $\begin{array}{l}-0.289 \\
{[-1.359]}\end{array}$ & $\begin{array}{l}1.460 \\
{[0.428]}\end{array}$ & $\begin{array}{l}-0.050 \\
{[-2.190]}\end{array}$ & $\begin{array}{l}0.001 \\
{[0.005]}\end{array}$ \\
\hline $\mathrm{D}(\mathrm{INFR}(-2))$ & $\begin{array}{l}-6.643 \\
{[-0.587]}\end{array}$ & $\begin{array}{l}-0.758 \\
{[-2.966]}\end{array}$ & $\begin{array}{l}-0.043 \\
{[-1.583]}\end{array}$ & $\begin{array}{l}-0.277 \\
{[-1.182]}\end{array}$ & $\begin{array}{l}2.311 \\
{[0.616]}\end{array}$ & $\begin{array}{l}-0.053 \\
{[-2.092]}\end{array}$ & $\begin{array}{l}0.193 \\
{[0.768]}\end{array}$ \\
\hline $\mathrm{D}(\mathrm{DR}(-1))$ & $\begin{array}{l}233.180 \\
{[2.089]}\end{array}$ & $\begin{array}{l}3.485 \\
{[1.526]}\end{array}$ & $\begin{array}{l}0.141 \\
{[0.521]}\end{array}$ & $\begin{array}{l}5.960 \\
{[2.583]}\end{array}$ & $\begin{array}{l}-46.873 \\
{[-1.267]}\end{array}$ & $\begin{array}{l}0.542 \\
{[2.156]}\end{array}$ & $\begin{array}{l}0.116 \\
{[0.047]}\end{array}$ \\
\hline $\mathrm{D}(\mathrm{DR}(-2))$ & $\begin{array}{l}224.640 \\
{[2.025]}\end{array}$ & $\begin{array}{l}3.725 \\
{[1.487]}\end{array}$ & $\begin{array}{l}0.339 \\
{[1.260]}\end{array}$ & $\begin{array}{l}0.032 \\
{[0.014]}\end{array}$ & $\begin{array}{l}-26.648 \\
{[-0.725\}}\end{array}$ & $\begin{array}{l}0.230 \\
{[0.918]}\end{array}$ & $\begin{array}{l}-2.082 \\
{[-0.845]}\end{array}$ \\
\hline $\mathrm{D}(\mathrm{ER}(-1))$ & $\begin{array}{l}-4.389 \\
{[-0.391]}\end{array}$ & $\begin{array}{l}-0.160 \\
{[-0.630]}\end{array}$ & $\begin{array}{l}-0.000 \\
{[-0.010]}\end{array}$ & $\begin{array}{l}-0.174 \\
{[-0.752]}\end{array}$ & $\begin{array}{l}3.246 \\
{[0.872]}\end{array}$ & $\begin{array}{l}-0.010 \\
{[-0.391]}\end{array}$ & $\begin{array}{l}-0.059 \\
{[-0.235]}\end{array}$ \\
\hline $\mathrm{D}(\mathrm{ER}(-2))$ & $\begin{array}{l}1.904 \\
{[0.190]}\end{array}$ & $\begin{array}{l}-0.009 \\
{[-0.0381]}\end{array}$ & $\begin{array}{l}-0.004 \\
{[-0.172]}\end{array}$ & $\begin{array}{l}-0.204 \\
{[-0.984]}\end{array}$ & $\begin{array}{l}3.126 \\
{[0.940]}\end{array}$ & $\begin{array}{l}0.021 \\
{[0.940]}\end{array}$ & $\begin{array}{l}0.399 \\
{[1.789]}\end{array}$ \\
\hline $\mathrm{D}(\mathrm{PKY}(1))$ & $\begin{array}{l}4.051 \\
{[3.174]}\end{array}$ & $\begin{array}{l}-0.000 \\
{[-0.016]}\end{array}$ & $\begin{array}{l}0.003 \\
{[0.915]}\end{array}$ & $\begin{array}{l}0.031 \\
{[1.193]}\end{array}$ & $\begin{array}{l}-0.181 \\
{[-0.427]}\end{array}$ & $\begin{array}{l}0.001 \\
{[0.313]}\end{array}$ & $\begin{array}{l}-0.027 \\
{[-0.940]}\end{array}$ \\
\hline $\mathrm{D}(\mathrm{PKY}(2))$ & $\begin{array}{l}2.416 \\
{[2.092]}\end{array}$ & $\begin{array}{l}-0.005 \\
{[-0.183]}\end{array}$ & $\begin{array}{l}0.003 \\
{[0.917]}\end{array}$ & $\begin{array}{l}0.024 \\
{[1.016]}\end{array}$ & $\begin{array}{l}0.052 \\
{[0.137]}\end{array}$ & $\begin{array}{l}0.004 \\
{[1.396]}\end{array}$ & $\begin{array}{l}-0.009 \\
{[-0.337]}\end{array}$ \\
\hline $\mathrm{D}(\mathrm{FD}(-1))$ & $\begin{array}{l}190.832 \\
{[1.694]}\end{array}$ & $\begin{array}{l}1.805 \\
{[0.710]}\end{array}$ & $\begin{array}{l}-0.020 \\
{[-0.073]}\end{array}$ & $\begin{array}{l}7.364 \\
{[3.164]}\end{array}$ & $\begin{array}{l}-52.505 \\
{[-1.406]}\end{array}$ & $\begin{array}{l}0.059 \\
{[0.233]}\end{array}$ & $\begin{array}{l}2.358 \\
{[0.943]} \\
\end{array}$ \\
\hline $\mathrm{D}(\mathrm{FD}(-2))$ & $\begin{array}{l}403.534 \\
{[2.453]}\end{array}$ & $\begin{array}{l}3.951 \\
{[1.063]}\end{array}$ & $\begin{array}{l}0.516 \\
{[1.295]}\end{array}$ & $\begin{array}{l}5.021 \\
{[1.476]}\end{array}$ & $\begin{array}{l}-21.983 \\
{[-0.403]}\end{array}$ & $\begin{array}{l}0.444 \\
{[1.198]}\end{array}$ & $\begin{array}{l}-3.723 \\
{[-1.019]}\end{array}$ \\
\hline $\mathrm{D}(\mathrm{NB}(-1))$ & $\begin{array}{l}-30.696 \\
{[-2.091]}\end{array}$ & $\begin{array}{l}-0.192 \\
{[-0.581]}\end{array}$ & $\begin{array}{l}-0.029 \\
{[-0.827]}\end{array}$ & $\begin{array}{l}-0.635 \\
{[-2.092]}\end{array}$ & $\begin{array}{l}1.748 \\
{[0.359]}\end{array}$ & $\begin{array}{l}-0.046 \\
{[-1.389]}\end{array}$ & $\begin{array}{l}0.173 \\
{[0.530]}\end{array}$ \\
\hline $\mathrm{D}(\mathrm{NB}(-2))$ & $\begin{array}{l}-19.377 \\
{[-1.575]}\end{array}$ & $\begin{array}{l}-0.034 \\
{[-0.123]}\end{array}$ & $\begin{array}{l}-0.024 \\
{[-0.796]}\end{array}$ & $\begin{array}{l}-0.035 \\
{[-0.137]}\end{array}$ & $\begin{array}{l}-0.855 \\
{[-0.209]}\end{array}$ & $\begin{array}{l}-0.015 \\
{[-0.532]}\end{array}$ & $\begin{array}{l}0.219 \\
{[0.800]}\end{array}$ \\
\hline $\mathrm{C}$ & $\begin{array}{l}899.345 \\
{[2.602]}\end{array}$ & $\begin{array}{l}4.744 \\
{[0.608]}\end{array}$ & $\begin{array}{l}0.100 \\
{[0.119]}\end{array}$ & $\begin{array}{l}21.448 \\
{[3.003]}\end{array}$ & $\begin{array}{l}-74.803 \\
{[-0.653]}\end{array}$ & $\begin{array}{l}0.482 \\
{[0.619]}\end{array}$ & $\begin{array}{l}-7.070 \\
{[-0.921]}\end{array}$ \\
\hline $\mathrm{R}^{2}$ & 0.581 & 0.487 & 0.512 & 0.693 & 0.447 & 0.546 & 0.317 \\
\hline F-Stat & 1.386 & 0.950 & 1.048 & 2.254 & 0.807 & 1.202 & 0.465 \\
\hline
\end{tabular}

From the result above, the model of interest is model 1 which is the model that carries the dependent variable D (DS). The result shows that the ECM is not correctly signed even though it is statistically significant. The coefficient of ECM of 0.765 shows that approximately $76.5 \%$ of the discrepancies between the long-run and the short-run dynamics are corrected annually but not correctly signed the implication is that the ECM does not have an effective correcting property as the short run and the long-run equilibrium will not converge in the long run. From the result, one period past domestic savings with the coefficient of -1.387 and at-value of -2.775 reveals that a unit increases in one period past domestic savings will cause domestic savings to decrease by 1.387 and it is statistically significant. Also, two periods past domestic savings with the coefficient of -0.436 and a tvalue of -1.216 reveals that a unit increases in two periods past domestic savings will cause current domestic savings to decrease by 0.436 but it's statistically insignificant.

The result shows that one-period past inflation rate with the coefficient of -14.219 and a t-value of -1.383 reveals that a unit increase in one period past inflation rate will cause current domestic savings to decrease by 14.219 though not statistically significant. Also, two periods past inflation rate with the coefficient of -6.643 and a t-value of -0.587 reveals that a unit increase in two periods past inflation rate will cause current domestic savings to decrease by 6.643 but it is statistically insignificant.

The result shows that one-period past deposit rate with the coefficient of 233.180 and a t-value of 2.089 reveals that a unit increase in one period past deposit rate will cause current domestic savings to increase by 233.180 and it is statistically insignificant. Also, two periods past deposit rate with the coefficient of 224.640 and a t-value of 2.025 reveals that a unit increase in two periods past deposit rate will cause current domestic savings to increase by 224.640 and it is statistically insignificant.

The result also reveals that one-period past exchange rate with the coefficient of -4.389 and a t-value of - 
0.391 reveals that a unit increase in one period past exchange rate will cause current domestic savings to decrease by 4.389 and it's statistically insignificant. Also, two periods past exchange with the coefficient of 1.904 and a t-value of -0.391 reveals that a unit increase in two periods past exchange rate will cause current domestic savings to decrease by 1.904 but it's statistically insignificant.

The result also revealed that one period past per capita income with the coefficient of 4.051 and a t-value of 3.174 reveals that a unit increase in one period past per capita income will cause current domestic savings to increase by 4.051 and it's significantly. Also, two periods past per capita income with the coefficient of 2.416 and a t-value of 2.092 reveals that a unit increase in two periods past per capita income will cause current domestic savings to increase by 2.416 but it's statistically significant.

The result also shows that one period past financial deepening with the coefficient of 190.832 and a t-value of 1.694 reveals that a unit increase in one period past financial deepening will cause current domestic savings to increase by 190.832 but statistically insignificant. Also, two periods past financial deepening with the coefficient of 403.534 and a t-value of 2.453 reveals that a unit increases in two periods past financial deepening will cause current domestic savings to increase by 403.534 and it's statistically significant.

The result revealed that one period past number of banks with the coefficient of -30.696 and a t-value of 2.091 reveals that a unit increase in one period past number of banks will cause current domestic savings to decrease by 30.696 and it's statistically significant. Also, two periods past number of banks with the coefficient of -19.377 and a t-value of -1.575 reveals that a unit increase in two periods the past number of banks will cause current domestic savings to decrease by 19.377 but it's statistically insignificant.

The coefficient of determination $\left(\mathrm{R}^{2}\right)$ of 0.581 shows that $58 \%$ of the systematic variations in domestic savings are due to the variations in the included regressor, while the remaining $41 \%$ is attributed to the error term. Thus judging by the coefficient of determination the estimated model has both high explanatory power and good predictive ability. The F-statistics of 1.386 exceeds the critical value at $5 \%$ level. This shows that the explanatory variables are at least simultaneously related to domestic savings (the dependent variable).

Long run regression results

Table 5: Long-run Results

\begin{tabular}{|l|l|l|l|}
\hline Regressors & Coefficients & T. Stat & Probability \\
\hline C & -9808.839 & -4.728 & 0.000 \\
\hline INFR & -32.164 & -1.499 & 0.150 \\
\hline DR & 651.453 & 5.106 & 0.000 \\
\hline ER & 48.214 & 7.062 & 0.000 \\
\hline PKY & 3.176 & 4.540 & 0.000 \\
\hline FD & 1.297 & 0.011 & 0.991 \\
\hline NB & 5.480 & 0.328 & 0.747 \\
\hline$R^{2} 0.948$ & Adj. $R^{2} 0.929$ & F-stat 48.582(0.000) & DW-stat 1.600 \\
\hline
\end{tabular}

The long run regression result above shows that all the variables are correctly signed. From the result, the coefficients of deposit rate, exchange rate, per capita income, financial deepening and number of banks of $651.453,48.214,3.176,1.297$ and 5.480 show that a unit increase in the variables respectively will bring about $651.453,48.214,3.176,1.297$ and 5.480 units increase in domestic savings. Also, the coefficients of inflation rate of -32.164 indicates that a unit increase in inflation rate will bring about 32.164 units decrease in domestic savings.

On the basis of the individual statistical significance of the model as shown by the t-values, the result shows that in the long run, deposit rate, exchange rate and per capita income have a significant impact on domestic savings since their t-values are greater than their critical $t$-values at $5 \%$ levels of significance. From the result the coefficient of determination of 0.948 shows that $95 \%$ systematic variations on public health expenditure is due to the variation in the explanatory variables in the model, while the remaining 5\% is attributed to the error term. When adjusted to its degree of freedom, the explained variation became $93 \%$. Thus judging from the coefficient of determination and their adjusted counterparts, the estimated models have both high explanatory power and good predictive ability.

The F-statistics of 42.57 is statistically significant at $5 \%$ level. This shows that there is a significant simultaneous relationship between the dependent variable and the independent variables in the model. These confirm that the model is of good fit. Lastly, the Durbin-Watson statistics of 1.6 which is approximately 2 shows the absence of autocorrelation in the model.

\section{CONCLUSION}

It was found in this research work that financial deepening has a significant impact on savings mobilization in Nigeria, the number of bank branches and per capita income have an impact on savings mobilization due to non- 
significant. Furthermore, inflation and exchange rate have inverse relationships with saving mobilization in Nigeria. Given this finding of this research work, the study showed that an increase in financial growth is very crucial as it leads to increased saving. Mobilization which is reduced for investment that will encourage economic development.

It is concluded that both in research and reality, there is lastly need for further efforts especially in mobilizing small savings in both urban and rural areas, and the process of financial intermediation itself. A commercial bank in performing their roles was formed to have potential scope and prospects for mobilizing financial resources and allocating them to investment. The commercial banks should offer simple and convenient financial instruments yielding a positive real return. The macroeconomic policy mix for raising the level of domestic savings and ensuring their efficient allocation needs to cover a wide range of institutional policy measures, comprising of greater financial intermediation, control of inflation through effective and aggregate demand management, positive and realistic rates of interest, tax incentives for personal savings, protection of the value of savings, integration of savings mobilization in macroeconomic policies at the organizational level and a long-run strategy of matching the growth of national income and per capita income by adequate supplies and availability of wage goods and incentive goods is essentials. The findings showed that financial deepening, real interest rate, inflation and real income per capita are the major determinants of savings in Nigeria.

\section{POLICY RECOMMENDATIONS}

Given the findings emanating from this research work, the following recommendations are made:

1. Efforts should be geared towards continuous and well-articulated fiscal and monetary policies that will sustain this growth in the financial sector.

2. The government should ensure adequate policies which will encourage Foreign Direct Investment (FDI) inflow and make Nigeria an export platform where export commodities could be manufactured. This will help to strengthen Nigeria's exchange rate and induce domestic savings.

3. Proper measures should be put into banks to encourage them to open branches in the rural areas to mop up deposits. The rural banking policies should be revisited modified and implemented in Nigeria.

4. Finally, there should be a need for the government to retain tight monetary and fiscal policies to fight inflation in the Nigeria economy. Since inflation has a negative and significant influence on domestic savings in Nigeria.

\section{REFERENCES}

Ayalew, H.A. (2013). "Determinants of Domestic Saving in Ethiopia": An Autoregressive Distributed lag (ARDL) Bounds Testing Approach. Journal of Economics and International Finance. 5(6): 248-257.

Babalola, K. (1991) Determinants of Savings in Nigeria: 1970-1989 Unpublished M.Sc Dissertation, Department of Economics, University of Ibadan

Davis, A.L (2013) "The Long Run Determinants of Private Domestic Saving in Ghana": A co-integration Approach. Journal of Economics and Sustainable Development 4(4) 125-137.

Egwakhide A.O. (2007).

Gersovitz, M. (1988) "Saving and Development" in H. Chenery and T.N. Scrinivason, (eds) Handbook of Development Economics, Northholland: Elsevier Science Publishers

Ghosh, D. (1986) "Savings Behaviour in the Non-Monetized Sector and its implications" Savings and Development No. 2

Giovannin, A. (1985) "Saving and the real interest rate in LDCS" Journal of Development Economics, 18, Pp. 197-217

Gobna, W.O. \& A. Nurudeen, (2009) "Long-Run Determinants of Savings in Nigeria" (1981-2007); Evidence from Time Series Data. The Nigerian Journal of Economics and Management Studies. 4(1): 87-106.

Goldsmith, R.W. (1969) Financial Structure and Development, New Haven: Yale University Press

Lewis W.A. (1955), External Economy and the Doctrine of Balanced Growth; Economic Journal LXV.241-51.

Miracle, M.P. \& C. Cohen (1980) "Informal Savings Mobilization in Africa" Economic Development and Cultural Charge Vol.28, No. 4 July

Modigliani, F. and A. A. Ando "The Life Cycle Hypothesis of Saving: Aggregate Implications and Tests. Review of Economics and Statistics, February 50, pp. 137-138

Mwega, F.M.S.M. Ngola and M.Mwangi (1990) "Real Interest rates and the Mobilization of Private Savings in Africa" African Economic Research Consortium, Research Paper 2 November

Nnanna O.J; A. Englama and F.O. Odoko (2004). " Finance, Investment and Growth in Nigeria", Abuja, Central Bank of Nigeria Bullion.

Nwachukwu, T.E \& Egwaikhide, F.O (2007). "An Error-Correction Model of the Determinants of Private Savings in Nigeria". A Paper presented at the African Economic Society (AES) Conference, Cape Town, South Africa 
Ogwumike, F.O. and D.A. Omole (1992) "Mobilizing Domestic Resources for Economic Development in Nigerian - The Role of Capital Market" African Economic Research Consortium Final Report May.

Olayemi, S.O. and M.O. Jolaosho (2013). "Real Interest Rate and Savings Mobilization in Nigeria". International Journal of Development and Economic Sustainability, 1(2): 28-40.

Olusoji, M.O (2003): "Determinants of Private Savings in Nigeria, an Error Correlation Approach" NDIC Quarterly Vol. 13, Pp. 85-96.

Philips A.O. (1990).

Rostow R.T. (1958).

Schumpeter J.A. (1934), AJ Nichol Journal of Political Economy. Journal.uchicago.edu.

Shirma A.Y. (1978).

Umoh, O.J (2003). “An Empirical Investigation of the Determinants of Aggregate National Savings Mobilization in Nigeria". African Economic Consortium, Research Paper, Nairobi, Kenya

Uremadu, S.O. (2007). "Core Determinants of Financial Savings in Nigeria: An Empirical Analysis for National Monetary Policy Formulation. International Review of Business Research Papers. 3(3):56-367

Uremadu S.O (2002). "Introduction to Finance", Benin Mindex Publishing Company Vittorio, C. and S. Klaus (1991) "Public Policies and Savings in Developing Countries" World Bank PRE Working Paper No. 574.

Virmani, A. (1986). The Determinants of Savings in Developing Countries. Theory, Policy and Research Issues. World Bank, August

Wafure, O.G. (2012). "Financial Sector Reforms and Private Savings": Evidence from Nigeria (1970-2009). WEEJS International Journal of Arts and Combined Sciences, 3(1,2): 1-12.

APPENDIX E: DATA PRESENTATION

\begin{tabular}{|c|c|c|c|c|c|c|c|}
\hline YEAR & DS & INFR & DR & ER & PCI & FDV & NB \\
\hline 1985 & 12.52 & 7.44 & 9.50 & 0.89 & 882.52 & 11.60 & 28 \\
\hline 1986 & 13.93 & 5.72 & 9.50 & 2.02 & 639.01 & 11.76 & 29 \\
\hline 1987 & 18.68 & 11.29 & 14.00 & 4.02 & 598.26 & 11.05 & 34 \\
\hline 1988 & 23.25 & 54.51 & 14.50 & 4.54 & 549.24 & 11.97 & 42 \\
\hline 1989 & 23.80 & 50.47 & 16.40 & 7.39 & 474.23 & 10.95 & 47 \\
\hline 1990 & 29.65 & 7.36 & 18.80 & 8.04 & 567.53 & 9.49 & 58 \\
\hline 1991 & 37.74 & 13.01 & 14.29 & 9.91 & 502.91 & 12.65 & 65 \\
\hline 1992 & 55.12 & 44.59 & 16.10 & 17.30 & 477.18 & 12.21 & 65 \\
\hline 1993 & 85.03 & 57.17 & 16.66 & 22.05 & 270.22 & 13.13 & 66 \\
\hline 1994 & 110.97 & 57.03 & 13.50 & 21.89 & 321.32 & 13.06 & 65 \\
\hline 1995 & 108.49 & 72.84 & 12.61 & 21.89 & 408.18 & 10.00 & 64 \\
\hline 1996 & 134.50 & 29.27 & 11.69 & 21.89 & 461.52 & 9.15 & 64 \\
\hline 1997 & 177.65 & 8.53 & 4.80 & 21.89 & 479.98 & 10.05 & 64 \\
\hline 1998 & 200.07 & 10 & 5.49 & 21.89 & 469.43 & 10.64 & 54 \\
\hline 1999 & 277.67 & 6.62 & 5.33 & 92.69 & 497.84 & 11.85 & 54 \\
\hline 2000 & 385.19 & 6.93 & 5.29 & 102.11 & 567.93 & 12.74 & 54 \\
\hline 2001 & 488.05 & 18.87 & 5.49 & 111.94 & 590.38 & 15.6 & 90 \\
\hline 2002 & 592.09 & 12.88 & 4.15 & 120.97 & 741.75 & 13.29 & 90 \\
\hline 2003 & 655.74 & 14.03 & 4.11 & 129.36 & 795.39 & 14.68 & 90 \\
\hline 2004 & 797.52 & 15 & 4.19 & 133.50 & 1007.87 & 12.31 & 89 \\
\hline 2005 & $1,316.96$ & 17.86 & 3.83 & 132.15 & 1268.38 & 11.85 & 25 \\
\hline 2006 & $1,739.64$ & 8.23 & 3.14 & 128.65 & 1656.42 & 13.25 & 25 \\
\hline 2007 & $2,693.55$ & 5.39 & 3.55 & 125.83 & 1883.46 & 15.54 & 24 \\
\hline 2008 & $4,118.17$ & 11.58 & 2.84 & 118.57 & 2242.87 & 20.45 & 24 \\
\hline 2009 & $5,763.51$ & 12.55 & 2.68 & 148.88 & 1891.34 & 21.25 & 24 \\
\hline 2010 & $5,954.26$ & 13.72 & 2.21 & 150.30 & 2292.45 & 20.21 & 24 \\
\hline 2011 & $6,531.91$ & 10.84 & 1.41 & 153.86 & 2520.4 & 19.33 & 24 \\
\hline 2012 & $8,062.90$ & 12.22 & 1.70 & 157.50 & 2746.99 & 19.37 & 21 \\
\hline 2013 & $8,656.12$ & 8.48 & 2.17 & 157.31 & 2998.07 & 18.92 & 24 \\
\hline 2014 & $12,008.24$ & 8.06 & 3.38 & 158.55 & 3222.69 & 18.24 & 24 \\
\hline 2015 & $11,458,13$ & 9.01 & 3.58 & 193.28 & 2730.43 & 19.68 & 25 \\
\hline 2016 & $12,310.71$ & 15.68 & 3.75 & 253.49 & 2176 & 21.31 & 25 \\
\hline 2017 & $12,957.22$ & 16.52 & 4.13 & 305.79 & 1968.56 & 19.67 & 26 \\
\hline 2018 & $15,067.12$ & 12.09 & 4.07 & 306.08 & 2028.18 & 19.63 & 27 \\
\hline
\end{tabular}

